\title{
Knowledge, Perception and Adaptation Strategies to Climate Change Among Farmers of Central State Nigeria
}

\author{
Mustapha Bello ${ }^{1}$, Salau E. S. ${ }^{1}$, O. E. Galadima $1^{1} \&$ Ali I. ${ }^{1}$ \\ ${ }^{1}$ Department of Agricultural Economics and Extension, Nasarawa State University, Keffi. Faculty of Agriculture, \\ Shabu- Lafia Campus, Nigeria \\ Correspondence: Mustapha Bello, Department of Agricultural Economics and Extension, Nasarawa State \\ University, Keffi. Faculty of Agriculture Shabu- Lafia Campus. E-mail: elmu457@yahoo.com
}

Received: January 30, 2013 Accepted: April 25, 2013 Online Published: May 27, 2013

doi:10.5539/sar.v2n3p107 URL: http://dx.doi.org/10.5539/sar.v2n3p107

\begin{abstract}
This study was designed to assess the knowledge, perception and adaptation strategies to climate change among farmers of central Nigeria. Multi-Stage sampling technique was used to source respondents for the study. Three out of the five local government areas (LGAs) were randomly selected in the study area. Five village communities were randomly selected from each of the five LGAs to give fifteen villages, while 10 farmers were also randomly selected from each village to give 150 respondents. Data collection was through an interview schedule. Simple descriptive statistics such as frequency counts, percentage and mean scores were used to achieve all the objectives of the study. Most of the respondents relied on radio as their major source of information on climate change. The perceived indicators of climate change by the respondents were excessive high temperatures, low and irregular rainfall pattern as well as low crop yields. Adaptation strategies used in the area included agroforestry practices, crop diversification, early maturing and disease/drought resistant varieties. The Major constraints to adaptation by the respondents were inadequate finance, poor infrastructures, unfavourable government/trade policies and poor technology. Extension agents in the study area should incorporate information on climate change in their extension messages.
\end{abstract}

Keywords: knowledge, perception, adaptation, climate change, strategy

\section{Introduction}

Climate change is perhaps the most serious environmental threat facing mankind worldwide. It affects agriculture in several ways, one of which is its direct impact on food production. Climate change, which is attributable to natural climate cycle and human activities, has adversely affected agricultural productivity in Africa and indeed Nigeria. Available evidences show that climate change is a global phenomenon, likewise its impacts, but the biting effects are more on the developing countries, especially those in Africa (including the study area) due to their low level of coping capabilities (Nwafor, 2007; Jagtap, 2007).

According to Warrick and Barrow (1991), climate change is a long term shift in the climatic pattern of a specific location, region or planet measured by changes in features associated with average weather components, such as temperature, wind patterns, and precipitation. The Inter-governmental Panel on Climate Change (IPCC, 2007) NIR defines climate change as a change in the state of the climate that can be identified by changes in the mean and/or the variability of its properties and persists for an extended period typically decades or longer, whether due to natural variability or as a result of human activity. The climate is said to have changed when the patterns and sequence of occurrence of weather events have shifted significantly from what they used to be over a period of time (FAO, 2008).

Climate change is therefore caused by both natural and man-made factors over a period of time. The natural processes implicated in climate change include volcanic eruptions, variations in the sun's intensity or very slow changes in ocean circulation or land surfaces which occur on time scales of decades, centuries or longer. However, human activities are by far, the major cause of climate change through the continuous release of green house gases and aerosols into the atmosphere by changing land surfaces and by depleting the stratospheric Ozone Layer (IPCC, 2001).

According to Department of International Development (DFID) (2004), Climate change with expected long-term 
changes in rainfall patters and shifting temperature zones are expected to have significant negative effects on agriculture, food and increased frequency and intensity of droughts and floods is expected to negatively affect agricultural production and food security. Climate change also results in northern and southern latitudes getting drier while the tropics are expected to become wetter DFID (2004) observed that climate variability is expected to increase with increased frequency and intensity of extreme weather conditions in Africa (including the study area). The implication is that most countries within the sub-region will experience more extreme weather conditions such as droughts, floods and high temperatures.

Agricultural production remains the main source of livelihoods for most rural communities in developing countries and sub-saharan Africa such as Nigeria in particular. In Nigeria, agriculture provides a source of employment for more than $60 \%$ of the population and contributes about $30 \%$ of the Gross Domestic product (GDP) (Kandlinkar \& Risbey, 2000). Climate change has greater negative impacts on poorer farm households as they have the lowest capacity to adapt to changes in climatic conditions. Adaptation measures are therefore important to help these communities to better face extreme weather conditions and associated climatic variations (Adger et al., 2003). This however depends on the level of awareness, knowledge and perception levels of the rural people on the causes, mitigation and adaptive techniques to climate change.Adaptation has the potential to significantly contribute to reductions in negative impacts from changes in climatic conditions as well as other changing socioeconomic conditions, such as volatile short-term changes in local and international markets (Kanlinker \& Risbey, 2000).

Small scale farmers who constitute the bulk of the poor in Africaand Nigeria, face prospects of tragic crop failures, reduced agricultural productivity, increased hunger, malnutrition and diseases (Zoellick, 2009). It is projected that crop yield in Africa and in Nigeria may fall by $10-20 \%$ by the year 2050 or even up to $50 \%$ due to climate change (Jones \& Thornton, 2003). Most farmers in Nigeria and particularly the study area, depend on rain fed agriculture and hence fundamentally are dependent on the vagaries of weather. This phenomenon threatens to deepen vulnerabilities, erode hard-won gains and seriously undermines prospects for development.

It is also observed that much of climate change that agricultural research has tended to concentrate on, assessing the sensitivity of various attributes of crop systems (e.g crop/ livestock yields, pests, diseases, weeds etc), the bio-physical aspects of food production, bore little or no regard to the socio-economic aspects. These partial assessments, most often consider climate change effects in isolation, providing little regard to the farmers about climate change phenomena, and how and what they are doing to cope with climate change. The coping capacity and adaptation strategies of the farmers depend to a very large extent on their perception knowledge level and sources of information about climate change available to them. Given the high level of illiteracy among rural farmers in the study area coupled with the poor nature of the public extension service, access to adequate information on climate change by these farmers is very poor. To better address the food security concerns that are central to national development, it is imperative to investigate the perception, knowledge level and adaptation strategies to climate change by rural farmers in the study area.

Climate change has become a new reality bringing in its wake changes in weather patterns, upsetting seasonal cycles and impacting negatively on ecosystems, farming systems and other livelihood processes. Farmers therefore need adequate knowledge on the nature and causes of climate change and the various mitigation and adaptation strategies to use. This of course, depends on their access to credible information sources and their capacity to apply the information.

This study will therefore bring to light the sources of information on climate change available to the respondents, their level of knowledge, perception and adaptation strategies used. These findings will serve as baseline information for policy makers and extension managers to design policy and programme on climate changes that will meet the needs and problems of farmers in the study area. Also the study will identify the indigenous adaptation strategies which could serve as building blocks for developing improved technologies that will be acceptable by the farmers in the area.Findings of this study will contribute to knowledge and serve as reference material for future studies.

The general objective of the study is to assess the knowledge, perception and adaptation strategies to climate change among farmers in central Nigeria.

The specific objective were to:

a. describe the socio-economic characteristics of the respondents.

b. describe the source of information on climate change used by the respondents.

c. assess the level of knowledge and perception of the respondents about changed phenomena. 
d. Identify the indigenous adaptation measures to cope with climate change; and

e. identify the problems encountered by the respondents to climate change effects.

\section{Methodology}

\subsection{Description of the Study Area}

The study was conducted inthe central part of Nigeria comprising five (5) local government areas namely: Awe, Doma, Keana, Lafia and Obi local government with headquarters at Obi.

The study area is located between latitudes $7^{\circ}$ and $9^{\circ} \mathrm{N}$ and longitudes $7^{\circ}$ and $10^{\circ} \mathrm{E}$. It shares boundaries with Benue state to the south, Kogi state to the west, the Federal Capital Territory (FCT) to the North West; Kaduna and Plateau States to the north east, and Taraba state in the south-east. The study area falls within the North-central geopolitical zone of Nigeria. It has a land area of $12,000 \mathrm{~km}^{2}$ and is divided into 13 Local Government Areas namely; Akwanga, Awe, Doma, Karu, Keana, Keffi, Kokona, Lafia, Nasarawa, NasarawaEggon, Obi, Toto and Wamba (Nasarawa State Government, 2008).

The population of the areais 1,863,275 (NPC, 2006). The major ethnic groups residing in the state include Afo, Agatu, Alago, Bassa, Egbura, Eggon, Fulani, Gade, Gbagyi, Gwandara, Hausa, Jukun, Kantana, Kanuri, Koro, Mada, Nya, nkpa, Rindre, Tiv. Agriculture is the most dominant occupation of the people. Major agricultural produce in the state include maize, sorghum, millet, rice, ground nut, cowpea. Also Soyabean, sesame, melon, yam, cassava, sweet potato sugar cane, tree fruit crops, livestock such as poultry, cattle, sheep, goats, pigs and fisheries are produced in the study area. The study area is also blessed with large solid mineral deposits such as granite, Berel, tourmaline quartz, limestone, marble, salt, and barites among others.

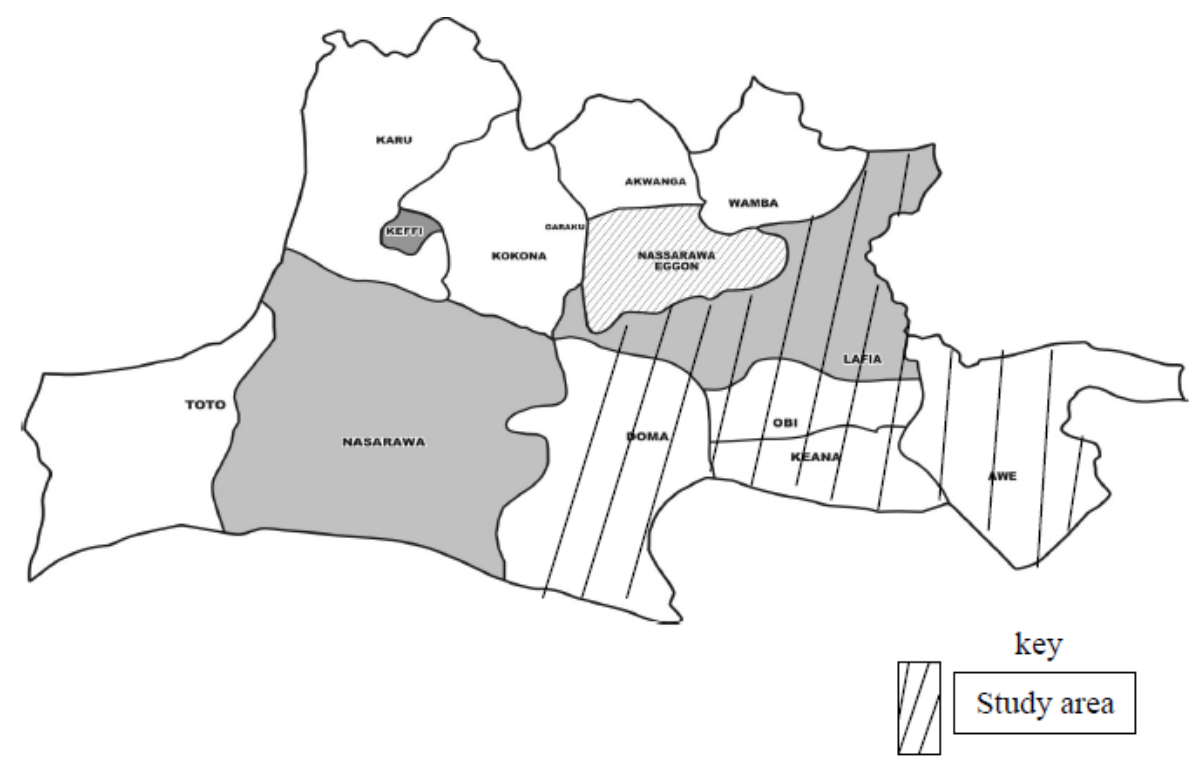

Figure 1. Map of Central part of Nigeria showing the study area

\subsection{Sampling Technique and Sample Size}

The study area is located in southern agricultural zone of Nasarawa Agricultural Development Programme (NADP) which comprises five LGAs. A multi-stage sampling technique was adapted for the study. Firstly three LGAs were randomly selected out of five LGAs. Subsequently, five farming communities (villages) were randomly selected from each of the three LGAs to give 15 villages. Finally ten (10) farmers were randomly selected from each of the 15 villages to get 150 respondents for the study.

\subsection{Data Collection}

The primary data were collected during the 2011 cropping season through structured interview schedule administered on the respondents. Data for the study were generated from primary sources in May, June and July. Developed questionnaire was validated by professional in the department of agricultural economics and extension of Faculty of Agriculture Shabu-Lafia Campus of Nasarawa State University, Keffi. The interview schedule was pre-tested at weekly interval in the study area and then enumerators who understood the local 
language well were used to assist in administering the questionnaire on the respondents.

About $48.0 \%, 20.6 \%, 2.0 \%, 33.3 \%$ and $26.0 \%$ of the respondents received 1 to 20,21 to 40,41 to 60,61 to 80 and 80 and above visits of extension personnel per year respectively. Mean extension visits in the study area was twenty-five (25). Benor and Baxter (1984) advised that annual visits to contact farmers by extension agents should be in the range of fifteen (15) to twenty (20).

\subsection{Data Analysis}

Data were analyzed using the statistical package for social sciences (SPSS). Descriptive statistics involving frequency counts, percentage, means and standard deviation were used to satisfy objectives $1,2,3$ and 4 . A 3-point Liker scale was used to satisfy objective 5 while a multiple regression model was used to test the hypothesis.

\subsection{Model Specification}

The explicit form of the regression model is given below:

$\mathrm{Y}=\mathrm{a}+\mathrm{b}_{1} \mathrm{x}_{1}+\mathrm{b}_{2} \mathrm{x}_{2}+\mathrm{b}_{3} \mathrm{x}_{3}+\mathrm{b}_{4} \mathrm{x}_{4}+\mathrm{b}_{5} \mathrm{x}_{5}+\mathrm{b}_{6} \mathrm{x}_{6}+\mathrm{b}_{7} \mathrm{x}_{7}=\mathrm{U}$

Where

$\mathrm{Y}=$ Adaptation index (No of adaptation measures used)

$\mathrm{a}=$ constant

$\mathrm{b}_{1}-\mathrm{b}_{7}=$ regression coefficients

$\mathrm{x}_{1}=$ Age of respondent in years

$\mathrm{x}_{2}=$ Gender $($ male $=1$, female $=2)$

$\mathrm{x}_{3}=$ Years of farming experience (years)

$\mathrm{x}_{4}=$ Farm size (hectare)

$\mathrm{x}_{5}=$ Level of formal education (years of schooling)

$\mathrm{x}_{6}=$ Annual income (in naira)

$\mathrm{x}_{7}=$ Extension contacts (No of visits per year).

$\mathrm{X}_{8}=$ Household size

$\mathrm{x}_{9}=$ Social organization belonged

$\mathrm{x}_{10}=$ Credit received

$\mathrm{x}_{11}=$ land tenure

The 3-point Likert rating

Very serious $=3$

Serious $=2$

Not serious $=1$

Mean $=3+2+1 / 3=6 / 3=2$

Decision rule: Any meanscore $\geq 2$ implies a serious constraint. Any meanscore $<2$ implies not serious constraint.

\section{Results and Discussion}

\subsection{Socio Economic Characteristics of Respondents}

Analysis of the age of the farmers in this study indicated $36.67 \%$ of them were between 31 and 40 years while $15.33 \%$ were between the age range of 51 to 60 years. The mean age of the respondents was 48 years (Table 1). This inferred that the majority of the respondents were within active age for agricultural production. The results agreed with Olayide (1989) who reported that farming activities grew with age.

The results of the study also revealed (Table 1) most (89.33\%) of the farmers were males and $10.67 \%$ were female. This implied male domination of farming activities in the study area.

About $34.0 \%$ of the participants had 21 to 30 years of farming experience, while $28 \%$ of them had farming experience of between 11 and 20 years and $20.0 \%$ had 31 to 40 experience respectively (Table 1 ). Also $10 \%$ and 
$8 \%$ of the respondents had above 40 years and below 10 years respectively. The mean years of farming experience of the respondents in the study area was 27 years. This implied that most of the respondents had been in the farming business for a long time. Years of farming experience were important because management skills improved with experience.

About $38.0 \%$ of the respondents had no formal education (Table 1) while $71.0 \%$ had secondary and tertiary education. Formal education enables farmers to obtain useful information from bulletins, agricultural newsletter and other sources. However, Agbamu (1996) opined that education level made negative contribution to adoption of TMS cassava and TZSR maize varieties. He believed that if a farmer had formal education but had no adequate knowledge of recommended farm practice, he was not likely to adopt it. The results (Table 1) of the study revealed that $41.33 \%$ of the respondents had farm size of 1 to 5 hectares, while $33.33 \%$ had 6 to 10 hectares ten (10) and above farm size respectively. Generally low farm size compounded by the use of hand tools by respondents made cultivation of large scale production difficult.

Data from the study (Table 1) revealed that $54 \% 30 \%, 12.67 \%, 26.67 \%$ and $0.67 \%$ of the respondents' household size was between 1 and 10,11 and 20,21 and 30,31 and 40 and 40 persons respectively. Mean household size in the study area was 12 persons. Household with large size tended to attach greater importance to food security than those with small size. This finding had implication for adoption level of technologies in the study area. It however signified that the farmers had a fairly large household, which could probably supply farm labour.

The results in Table 1 revealed about $50.0 \%$ of the respondents belonged to one to two social organizations, $34.67 \%$ of them did not belong to any social organization. Also $14.67 \%$ of the respondents belonged to between 3-4 different social organizations. Membership of social organization enhances access to information and adoption of improved technologies and material inputs of the technologies.

The mean annual income of $56.67 \%$ of the respondents was between $\mathrm{N} 1,000$ to $\mathrm{N} 200,000$, while $15.33 \%, 12.0 \%$, $8.67 \%, 11.33 \%$ of the respondents had N401, 000 to N600,000; N201,000 to N400,000, N601,000 to N800,000, $\mathrm{N} 801,000$ to N1,000,000 and above N1,000,000 respectively. Agbamu (2006) reported that it was not always easy to determine the level of income of Nigerian farmers because some of them did not keep records while others were skeptical about disclosing their income. He was however, of the view that the higher the income level of a farmer the less he or she would be disposed to fear of taking risk in respect of adopting a given technology. He further argued that poor economic status of most Nigerian farmers had inhibited the adoption of most agricultural technologies because of innovation perceived as advantageous may not be adopted as a result of cost.

The results of the study revealed that $73.33 \%$ of the respondents did not receive any form of credit, while $18.67 \%$ of them received credit of between N1000 to N100, 000 (Table 1).This inferred inability to acquire inputs embodied in new technology and also to pay for hired labour needed for the use of these inputs and improved management for the technology.

Most (76.67\%) of the respondents (Table 1) acquired land through inheritance, while $11.33 \%$ of the respondents used family/community land tenure system. Hired, Purchased and leased land tenure system occupied by $6.67 \%$, $4 \%$ and $1.33 \%$ of the respondents respectively. The study showed that land ownership by respondents in the study area was permanent. Tenure status brought along with it insecurity of tenure which was disincentive to permanent investment on land. Since investment in farming activities was of a permanent nature. Small holders like the farmers in the study area were likely to accept more of the improved technologies when they owned the land.

Table 1. Distribution of respondents according to their socioeconomic characteristics $n=150$

\begin{tabular}{llll}
\hline Variable & Frequency & Percentagex & \\
\hline X & & & \\
Below 21 & 1 & 0.67 & \\
$21-30$ & 5 & 3.33 & \\
$31-40$ & 43 & 28.67 & \\
$41-50$ & 55 & 36.67 & 48 \\
$51-60$ & 23 & 15.33 & \\
Above 60 & 23 & 15.33 & \\
Gender & & & \\
Male & 134 & 89.33 & \\
\hline
\end{tabular}




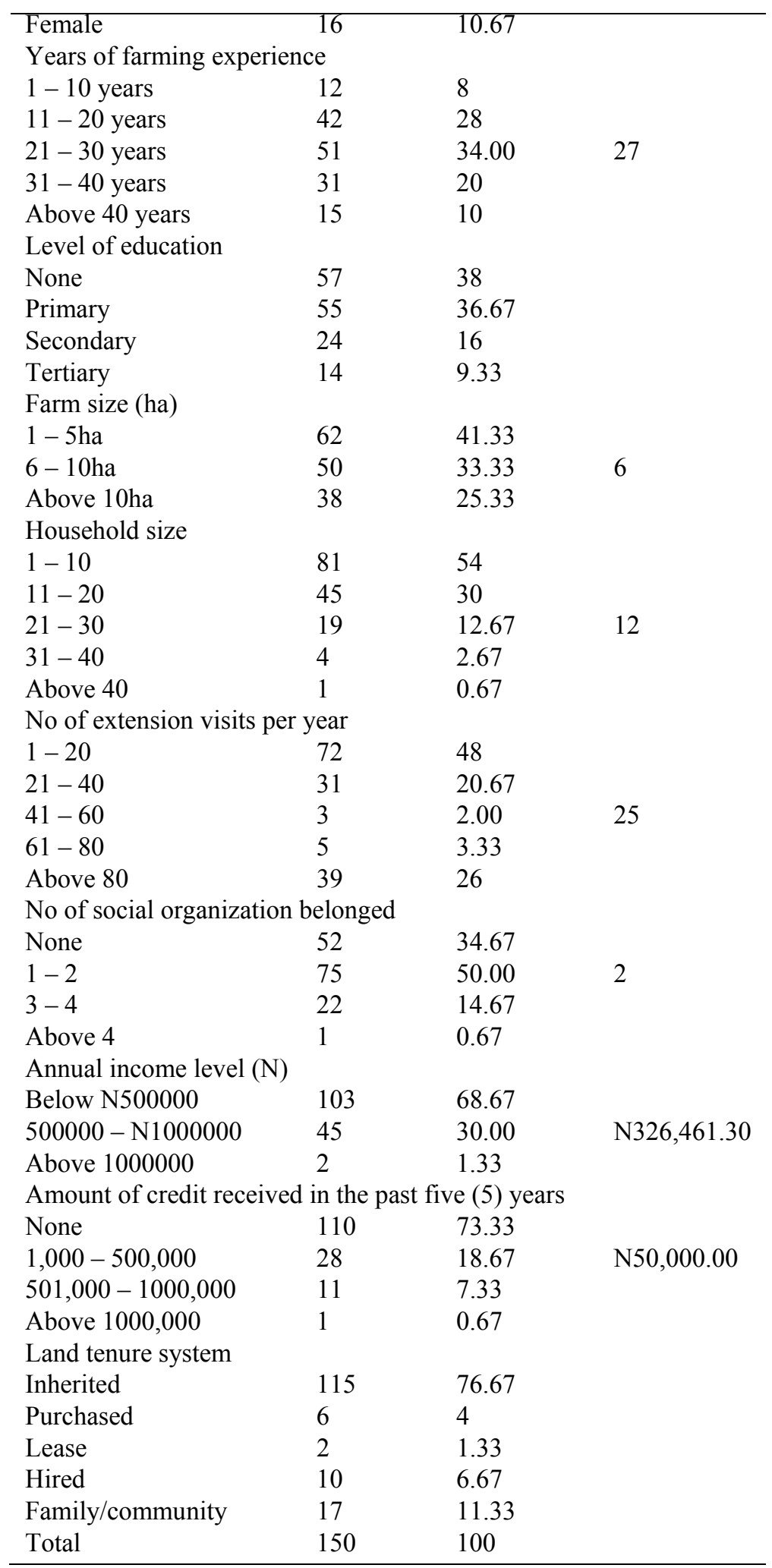

Source: Field survey data, (2011).

\subsection{Sources of Information on Climate Change}

Table 2 reveal $68.0 \%$ of the respondents used radio as their source of information while $38 \%$, and $30 \%$ secured information on climate change from extension agents and television respectively. This inferred radio as the most widely used source of information on climate change by the respondents. According to Nhemachen and Hassan 
(2007) information through extension agents enhanced more the chances of adapting to climate change.

Table 2. Distribution of respondents according to the sources of information on climate change $n=150$

Multiple responses recorded.

\begin{tabular}{lll}
\hline Sources & Frequency & Percentage \\
\hline Radio & 102 & 68 \\
Television & 45 & 30 \\
Extension agents & 57 & 38 \\
Internet & 3 & 2 \\
Meteorological station & 9 & 6 \\
Fellows farmers & 14 & 9.33 \\
Cooperative societies & 9 & 6.33 \\
Religious bodies & 1 & 0.67 \\
Print media & 1 & 0.67 \\
\hline
\end{tabular}

Source: Field Survey (2011).

\subsection{Knowledge and Perception Levels of Climate Change of Respondents}

A total of $60.67 \%$ of the respondents perceived high level of temperature (Table 4 ) while $58.67 \%$ of the survey farmers regarded low rain fall distribution as the major indicators of climate change in the study area. Similarly, $15.33 \%$ and $11.33 \%$ of the respondents were of the view that drought, high level of rainfall and reduction in production output were significantly contributory to climate change. In the same vein $6.67 \%, 4.6 \%$ and $2.0 \%$ of the respondents claimed extreme cool temperature, increase in the level of ocean current and excess sun shine as the major indicators of the climate change in the study area. Knowledge and perception of the respondent critically identify high temperature, low level of rainfall and low crop yields were most contributory indicators to climate change in the study area.

Table 3. Distribution of respondents according to their level of knowledge and perception of climate change $\mathrm{n}=$ 150

\begin{tabular}{lll}
\hline Indicator of climate change & Frequency & Percentage \\
\hline High temperature & 91 & 60.67 \\
Low Rainfall & 88 & 58.67 \\
Drought occurrence & 23 & 15.33 \\
High rainfall & 17 & 11.33 \\
Extreme cool temperature & 10 & 6.67 \\
Low output & 15 & 10 \\
Raising level floods & 7 & 4.67 \\
Excess sunshine & 3 & 2 \\
\hline
\end{tabular}

Multiple responses.

Source: Field survey data (2011).

\subsection{Indigenous Adaptive Measures Used by the Respondents}

Table 4 reveal half (53.33\%) of the respondents adopted disease resistant crop varieties as an adaptation measure to climate change, while $52.67 \%, 48.0 \%, 46.67 \%$, and $38.67 \%$ adopted agro-forestry, crop diversification; early planting of crops and short maturing crop varieties as measures to climate change respectively. In the same vein application of minimum tillage, use of cover cropping, adoption of irrigation farming and use of mulching accounted for adoptive practices by $25.33 \%, 25.00 \%, 22.00 \%$ and $11.33 \%$ of the respondents respectively. Farm insurance as an adaptive measure accounted for 3.33\% of the respondents. The results of the study showed crop diversification and early maturing crops constituted the bulk of adoptive measures by the respondents against 
climate change in the study area.

Table 4. Distribution of respondents according to types of indigenous adaptation measure used $(n=150)$

\begin{tabular}{lll}
\hline Types of adaptation measure & Frequency & Percentage \\
\hline Crop diversification & 72 & 48 \\
Early planting of crops & 70 & 46.67 \\
Minimum soil tillage & 38 & 25.33 \\
Use of mulching & 17 & 11.33 \\
Use of cover cropping & 38 & 25 \\
Agroforestry practices & 78 & 52.67 \\
Farm insurance & 5 & 3.33 \\
Planting early maturing varieties & 58 & 38.67 \\
Disease/drough resistant & 80 & 53.33 \\
Adoption of irrigation techniques & 33 & 22 \\
\hline
\end{tabular}

Multiple responses.

Source: Field survey data (2011).

\subsection{Perceived Factors Militating Against Adaptive Capacity}

Table 5 shows the mean scores of the respondents perceived factors militating against adaptive capacity of the farmers in the study area. Using a 3-point Likert scale rating (with response options very serious $=3$, serious $=2$ and not serious =1) A list of 14 possible constraints were presented for the respondents to rate, 13 factors were rated as serious constraints by the respondents. These includes, use of traditional farming system $(x=2.19)$, low capital ( $\mathrm{x}=2.59)$, low level of technology $(\mathrm{x}=2.31)$, low level of education $(\mathrm{x}=2.23)$; inadequate information on climate change $(x=2.19)$ unfavourable land tenure system $(x=2.21)$; lack of conclusive and stable government policies $(\mathrm{x}=2.36)$, globalization and trade liberalization $(\mathrm{x}=2.31)$; weak institution and bad government $(\mathrm{x}=2.35)$; poor market facilities $(\mathrm{x}=2.23)$; hunger and poverty $(\mathrm{x}=2.00)$; poor infrastructure $(\mathrm{x}=2.55)$ and poor health status of the farmers $(x=2.55)$ and poor health status of the farmers $(x=2.05)$. Meanwhile only 1 out of 14 factors only extension service, not a constraint to farmers in the study area. The findings of the study inferred that respondents in the study area had limited choice of farming activities. In Nigeria extension agents are the main sources of farmers' information on improved agricultural technologies. They are also responsible for educating farmers on the use of improved technologies. Extension service was not a significant constraint probably because it was provided free to serve as motivating factor for technology adoption.

Effects of farmer's socioeconomic characteristics on their adaptive capacity (no of adaptation measures used). The result of the regression analysis in table 6 shows that several characteristics of the respondents influence either positively or negatively their adaptive capacity to climate change.

Factors that were highly significant at $1 \%$ level include farming experiences, number of extension contacts per year, income level and type of land tenure system used. Factors that were significant at 10 percent were age, educational level, and use of farm credit. The $\mathrm{R}$ square value of 0.544 implies that about $54 \%$ of the adaptive capacity of the respondents was determined by their socio-economic characteristics. 
Table 5. Distribution of respondents according to factors affecting their adaptive capacity

\begin{tabular}{lllllll}
\hline \multirow{2}{*}{\multicolumn{1}{c}{ Factors }} & \multicolumn{3}{c}{ level of seriousness } & & $\begin{array}{c}\text { Total } \\
\text { scores }\end{array}$ & $\begin{array}{l}\text { Means } \\
\text { scores }\end{array}$ \\
\cline { 2 - 5 } & Very serious & Serious & Not serious & & \\
Use of traditional farming system & 204 & 86 & 39 & 329 & $2.19^{*}$ \\
Low capital & 276 & 108 & 4 & 388 & $2.59^{*}$ \\
Low level of technology & 186 & 144 & 16 & 346 & $2.31^{*}$ \\
Low level of education & 153 & 166 & 16 & 335 & $2.23^{*}$ \\
Inadequate information on climate change & 123 & 194 & 12 & 329 & $2.19^{*}$ \\
Poor extension services & 69 & 188 & 33 & 290 & 1.93 \\
Unfavourable land tenure system & 138 & 158 & 35 & 331 & $2.21^{*}$ \\
Lack of conducive and & 207 & 132 & 15 & 354 & $2.36^{*}$ \\
stable government policies & & & & & \\
Globalization and trade liberalization & 171 & 164 & 11 & 346 & $2.31^{*}$ \\
Weak institution and bad government & 192 & 148 & 12 & 352 & $2.35^{*}$ \\
Poor market facilities & 156 & 162 & 17 & 335 & $2.23^{*}$ \\
Hunger and poverty & 105 & 158 & 37 & 300 & $2.00^{*}$ \\
Poor infrastructure & 294 & 74 & 15 & 383 & $2.55^{*}$ \\
Poor health status of the farmers & 114 & 162 & 31 & 307 & $2.05^{*}$ \\
\hline
\end{tabular}

* = serious constraint.

Source: Field survey, (2011).

Table 6. Coefficients

\begin{tabular}{llllll}
\hline \multirow{2}{*}{ Model } & \multicolumn{2}{c}{$\begin{array}{c}\text { Unstandardized } \\
\text { Coefficients }\end{array}$} & $\begin{array}{l}\text { Standardized } \\
\text { Coefficients }\end{array}$ & & S \\
\cline { 2 - 4 } & B & Std. Error & Beta & & \\
\hline Constraint & 42.165 & 10.862 & & 3.882 & 0 \\
Age in years & -0.503 & 0.226 & -0.239 & -2.227 & 0.028 \\
Sex of resp. & 5.712 & 5.023 & 0.07 & 1.137 & 0.257 \\
Farm exp in years & 0.905 & 0.261 & 0.399 & 3.465 & 0.001 \\
Years of schooling & -0.58 & 0.323 & -0.123 & -1.797 & 0.074 \\
Farm size in hectares & -0.027 & 0.273 & -0.007 & -0.099 & 0.921 \\
No of persons in household & -0.103 & 0.222 & -0.036 & -0.463 & 0.644 \\
No of extension visit/year & -0.145 & 0.028 & -0.326 & -5.142 & 0 \\
No of social organizations belonged & 1.333 & 1.489 & 0.06 & 0.895 & 0.372 \\
Annual income in naira & $2.99 \mathrm{E}-05$ & 0 & 0.354 & 5.184 & 0 \\
Amount of credit received in naira & $-2.66 \mathrm{E}-05$ & 0 & -0.145 & -2.297 & 0.023 \\
Type of tenure system & -4.009 & 1.112 & -0.228 & -3.605 & 0 \\
\hline
\end{tabular}

Source: Field survey (2011).

\section{Conclusion and Recommendations}

\subsection{Conclusion}

From the findings of this study it can be concluded that most (89\%) of the respondents in the study area were 
male. The major source of information on climate change in the study area was the use of radio. Their knowledge and perception of climate change phenomenon substantially directed at high temperature, decreased rainfall distribution low production output. The adaptation measures mostly used by the respondents were the use of disease resistant crop varieties, agroforestry practices, crop diversification, crop planting and use of cover cropping.

\subsection{Recommendations}

Based on the findings of this study, the following recommendations were made:

a. Enhanced literacy campaigned be pursued through radio programming to increase farmers' awareness on climate change in the study area.

b. Adequate and regular information on current issues related to the effect of climate change on agriculture be provided to the respondents through mass media campaign specially radio.

c. Farmers should be encouraged to form viable farmers' radio listening groups to enhance their accessibility to modern ICT facilities so as to improve their capacity to understand the causes of climate change and various mitigating strategies for adaptation.

d. Effort should be made to establish good source of agricultural loans and credit facilities accessible to respondents so as improve their adaptation capacity to climate change.

e. Appropriate stable policies on climate change mitigation and adaptation must be pursued by relevant authority while appropriate extension delivery message be made available to help farmers cope with the effect of climate change.

\section{References}

Agbamu, J. U. (2006). Essentials of Agricultural Communication in Nigeria (1st ed.). Benin: Malthouse Press, Limited.

Asfaw, A., \& Admassie, A. (2004).The role of education on the adoption of chemical fertilizer under different Socioeconomic Environment in Ethiopia. Journal of Agricultural Economics, 30(3), 315-228.

Chris, D., \& Sanders, R. (1992). People and Environment. Heineman Educational: Oxford, London.

Croppenstedt, A., Demeke, M., \& Meschi, M. M. (2003). Technology Adoption in the Presence of Constraints. Review of Development Economics, 7(1), 58-70. http://dx.doi.org/10.1111/1467-9361.00175

Davidson, O. R. (1998). The Climate Convention and Kyoto Agreements: Opportunities for Africa. Kyotoi

Edwards P. G., \& Japan, C. A. M. (2001). Changing the Atmosphere: Expert knowledge and environmental governance. Cambridge Massi: MIT Press. http://dx.doi.org/10.1016/S1352-2310(00)00359-9

Fakhri, B., \& Sombroek, W. (1996). Global Climate Change and Agricultural production (pp. 1-5). John Wiley \& Sons Ltd. Baffins Lane, Chichester. West Sussex: England.

Food and Agricultural Organization (FAO). (2008). Confronting Climate Change through Cooperatives Enterprise Message from the Agriculture Organization of the United Nations during the $11^{\text {th }}$ UN International Day of Cooperatives, FAO Rome: Italy.

Hassana, T. A. (2010). Nigeria Climate Change and Food Change. Retrieved August 7, 2010, from htt://www.allafrica.com/howto.htm

Kurakulasuriya, P., \& Mendelsotun, R. (2006). Indigenous Irrigation: The impact of Climate Change on Farmers in Africa.CEEPA Discussion Paper No. 18 Centre on Environment Economics and Policy in Africa. Pretoria South Africa: University of Pretoria.

Maddison, D. (2006). The Perception and Adaptation to Climate Change in Africa. CEEPA, Pretoria. South Africa: University of Pretoria (Chapter 3).

Mckibben, B. (2011). The Global Warning Reader: New York, N.Y.

Mudhara, M., Hildebrand, P. E., \& Gladwin, C. H. (Undated). Gender-Sensitive LP Models in Soil Fertility Research for Smallholder Farmers: Reaching De Jure Female headed Households in Zimbabwe. African Studies Quarterly, Retrieved from http://web.africa.ufl.edu/asg/v6/v6ila12.htm

Mugabe, F. T., Hodnett, M., \& Senzanje, A. (2007). Comparative Hydrological Behaviour of Two Small Catchments in Semi-arid Zimbabwe. Journal of Arid Environments, 69(4), 599-616. http://dx.doi.org/10.1016/j.jaridenv.2006.11.016 
National Meteorological Service Agency (NMSA). (2001). Initial National Communication of Ethiopia to the United Nations Framework Convention on Climate Change (UNFCCC) (pp. 25-30). Ethiopia: Addis Ababa.

Ndebele, J. J., Muchenje, V., Mapiye, C., Chimonyo, M., Musemwa, L., \& Ndlovu, T. (2007). Cattle Breading Management Practices in the Gwayi Smallholder Farming area of South-western Zimbabwe. Livestock Research for Rural Development, 19(12). Retrieved from http://lrrd.cipav.org.co/lrrd19/12/ndeb19183.htm

Nhemachena, C., \& Hassan, R. (2007). Micro-level Analysis of Farmers' Adaptation to Climate Change in Southern Africa. IFPRI: Discussion paper No. 00714. International food policy Research Institute: Washington DC.

Olayide, S. O., \& Headly, E. O. (1982). Introduction to Agricultural Economics. Ibadan University Press. University of Ibadan, Nigeria.

Oxfam. (2007). Adapting to Climate Change: what's needed in Poor Countries and who should Pay. Oxfam Briefing paper104, May: Oxfam International.

Phillips, A. O., \& Titilola, T. (1995). Indigenous Knowledge Systems and Practices: Case Studies from Nigeria. NISER: Ibadan Nigeria.

Saul, I., Douglas, L., \& Johnson, D. W. (1977). World Geography Today (p. 36). New York: Rinehert and Winston Publisher.

Scharfer, Y. (1991). Utilizing Indigenous Agricultural Knowledge in the Planning of Agricultural Research Projects designed to aid Small-scale farmers.

Sidhu, R. (2008). Global Environmental Changes and Food Security in Indo Gangetic Plains: Issues and Activities. Paper Presented at the Food Security and Environmental change Conference: Oxford England.

Slater, R., Peskett, L., Ludi, E., \& Brown D. (2007), Climate Change, Agricultural Policy and Poverty Rejection-how much do you know.Natural Resource Perspectives, September, 2007. p. 109.

Tekere, M., \& Hurungo, J. (2003). The Status of Agriculture Trade and Liberalization in SADC Countries. The Case for Zimbabwe. Southern AfricanTrade and Development Newsletter No 9 (March 2003).

Warrick, R. A., \& Barrow, E. M. (1991). Climate Change Seenariosfor the UK. Transactions of the Institute of Geographers, 16, 397-399.

Wein, R. J. T., Schipper, E. L., \& Dessai, S. (2003). Integrating Mitigation and Adaptation into Climate and Development Policy.

Yirga, C. T. (2007). The Dynamics of Soil Degradation and Incentives for Optimal Management in Central Highlands of Ethiopia. Ph.D thesis. Department of Agricultural Economics, Extension and Rural Development. University of Pretoria: South Africa. 